\title{
Whose Tradition?
}

Discourses on the Built Environment

Edited by

Nezar AlSayyad

Mark Gillem

David Moffat 


\section{Contents}

711 Third Avenue, New York, NY 10017

Routtedge is an imprint of the Taylor \& Francis Group, an. Informa business

Preface

individual chapters: the contributors

The right of the authors has been asserted in accordance with sections 77 and 78 of the Copyright, Dcsigns and Patents Act 1988.

All rights reserved. No part of this book may be reprinted or reproduced or utilized in any form or by any electronic, mechanical or other means, now known or hereafter invented, including photocopying and recording, or in any information storage or retrieval system, withott permission in writing from the publishers.

The publisher makes no represcntation, express or implied, with regard to the accuracy of the information contained in this book and cannot accept any lcgal responsibility or liability for any crrors or omissions that may be made.

Tridemark notice: Product or corporate names may be trademarks or registered trademarks, and are used only for identification and explanation without intent to infringe.

British Libtary Cataloguing in Publication Date

A cataloguc record of this book is available from the British Library

Library of Congress Catnloging in Publication Data

Names: Alsayyad, Nezar, editor:

Titlc: Whose tradition? : discourses on the built cnvironment / [editors] Nezar Alsayyad, Mark Gillem, David Moffat.

Description: Ncw York : Routledge, 2017. | Series: Planning, history and environment

serics | Includes bibliographical references and index.

Identifiers: LCCN 2017011643| ISBN 9781138192072 (hardback) | ISBN

9781315640112 (cbook)

Suhjects: LCSI-I: Architecture and socicty. | Identity (Psychology) in architecture.

Classification: LCC NA2543.S6 W498 2017 | DDC 720.1/03-dc23

LC record available at https://lcen.loc.gov/2017011643

ISBN: 978-1-138-19207-2 (1hbk)

ISBN: 978-1-315-64011-2 (cbk)

Typeset in Aldine and Swiss by PNR Design, Didcot

The Editors and Contributors

Prologue

Whose Tradition?

Nezar AlSaryad

Part I: Place: Whose Nation, Whose City?

1 Tradition and Its Aftermath: Jakarta's Urban Politics Abidin Kusno

2 Tradition as an Imposed and Elite Inheritance: Yangon's Modern Past

Jayde Lin Roberts

3 Mega-Events, Socio-Spatial Fragmentation, and Extraterritoriality in the City of Exception: The Case of Pre-Olympic Rio de Janeiro

Anne-Marie Broudehoux

Part II: People: Whose Indigeneity?

4 Revamping Tradition: Contested Politics of 'the Indigenous' in Postcolonial Hong Kong

Shi-Mei Huang

5 Their Voice or Mine? Debating People's Agency in the Construction of Adivasi Architectural Histories

Gauti Bharat

6 Malaysianization, Malayization, Islamization: The Politics of Tradition in Greater Kuala Lumpur

Tim Bunnell 


\section{Part III: Colonialism: Whose Architecture?}

7 How the Past and the Future Have Influenced the Design of Guam's Government House

Marvin Brown

8 The Missing 'Brazilianness' of Nineteenth-Century Brazilian Art and Architecture

Pedro Paulo Palazzo and Ana Amélia de Paula Moura

9 Empire in the City: Politicizing Urban Memorials of Colonialism in Portugal and Mozambique

Tiago Castela

\section{Part IV: Time: Whose Identity?}

10 Whose Neighbourhood? Identity Politics, Community Organizing, and Historic Preservation in St. Louis Susanne Cowan

11 Cosmopolitan Architects and Discourses of Tradition and Modernity in Post-Independence Africa Jennifer Gaugler

12 New Traditions of Placemaking in West-Central Africa Matk Gillem and Lyndsey Deaton

\section{Reflections}

13 The Agency of Bclonging: Identifying and Inhabiting Tradition Mike Robinson

14 Process and Polemic Dell Upton

Index

\section{Preface}

Tradition has been the subject of many books and much research by scholars from many disciplines. Tradition's relationship to the built environment has been the focus of researchers and scholars who present their work at the meetings and in publications of the International Association for the Study of Traditional Environments (IASTE), which I co-founded in 1988. Recent IASTE conferences have dealt with tradition's relationship to development, utopia, and myth, and these conferences have advanced multiple perspectives regarding the construction of tradition and sustained IASTE's long-term position that tradition is not the static legacy of a past, but rather a contemporary project for a dynamic reinterpretation of this past in the service of the future. To understand how traditions are tied to notions of time and space, we asked the question 'Traditions of Whom?'. We went further to ask whose interests are present in the invocations of tradition, particularly in the making of the built environment. This question 'Whose Tradition?' was the theme of the 2014 IASTE conference held in Kuala Lumpur, Malaysia in December of that year. As in past IASTE conferences, scholars and practitioners from architecture, architectural history, art history, anthropology, geography, planning, and urban studies submitted papers that addressed the theme. This book contains a few of these papers revised as chapters to fit the different parts of the book and complemented by a few others that were not presented at the conference.

As part of passing on the baton and hence sustaining a tradition, I have asked Mark Gillem and David Moffat, my long time associates and IASTE fellows, to join $\mathrm{mc}$ in editing this volumc. Many individuals deserve thanks for their effort to make this book a reality. First, I must acknowledge Jennifer Gaugler, the IASTE Conference Coordinator in Kuala Lumpur, for her exccllent management of the conference. Victoria Duong, the IASTE Executive Coordinator, deserves special recognition for her effort in corresponding with the authors, managing the submission process, maintaining all the records and acquiring the proper releases. Lyndscy Dcaton, the IASTE Liaison in Eugenc, was ably responsible for revising the papers and turning them into chapters according to the publisher's guidelines in collaboration with David Moffat. Finally, I must thank Ann Rudkin, my long time editor. 'This book marks our sixth collaboration over a fifteen-year period, and I am grateful for all of her guidance on these book projects.

Nezar AlSayyad

Berkeley, 2017 


\section{The Editors and Contributors}

\section{The Editors}

Nezar AlSayyad is an architect, planner, urban historian, and public intellectual. He is Professor of Architecture, Planning, and Urban Design at the University of California at Berkeley where he currently serves as the Faculty Director of the Center for Arab Societies and Environments Studies (CASES). He is the Co-founder of the International Association for the Study of Traditional Environments (IASTE), and currently its President and Editor of its journal, Traditional Dwellings and Settlements Review (TDSR). AlSayyad is the recipient of many grants for his research, books, films, and projects from the US National Endowment of the Arts (NEA), the Graham Foundation, the Getty Foundation, the Ford Foundation, the Woodrow Wilson Center in Washington DC, the Doris Duke Foundation, and the US Department of Education. Among AlSayyad's numerous awards are the Pioneer America Society Best Book Award in 1988, the American Institute of Architects Education Honors in 1991, and more rccently a Distinguished Guggenheim Fellowship for 2014-2015. In 2008, the University of California recognized his work with the Distinguished Teaching Award, the highest recognition given to a faculty member on the Berkeley campus. AlSayyad is the author, co-author, editor, or co-editor of many books, among them Streets of Isiamic Cairo (1981); Dwellings, Settiements and Tradition (1989); Cities and Caliphs (1991); Forms and Dominance (1992); Consuming Tradition, Manufacturing Heritage (2001); Hybrid Urbanism (2001); Muslim Europe or Euro-Istam (2002); The End of Tradition (2004); Making Cairo Medieval (2005); Cinematic Urbanism (2006); The Fundamentalist City? Religiosity and the Remaking of Urban Space (2010); Cairo: Histories of a City (2011); and Traditions: The Real, the Hyper, and the Virtual in the Built Environment (2014).

Mark Gillem is Professor of Architecture, Landscape Architecture, and Urban Design at the University of Oregon. His book America Town: Building the Outposts of Empire (2007) draws on a decade in the US Air Force, both as an architect and planner and as a faculty member of the Air Force Institute of Technology. America Town examines the forces behind the 
exportation of the American lifestyle to military bases abroad and explores the impact of this approach on foreign lands. He also contributed an essay on this topic to Indefensible Space: The Architecture of the National Insecurity State, edited by Michael Sorkin (2007). Gillem addresses sustainability, social responsibility, and historic preservation through his research and his professional practice. He received recognitions from the American Planning Association for air base master plans in Korea and Texas. Other honours include a Design Excellence Award from the US Air Force and the Crocker Award for Teaching Excellence at the Air Force Institute of Technology. Gillem is the Director of the International Association for the Study of Traditional Environments (IASTE). Hc is Principal of his practice, The Urban Collaborative. Gillem is also a fellow of both the American Institute of Architects (FAIA) and the American Institute of Certified Planners (FAICP).

David Moffat is an architect and planner in Berkeley, CA, and editor of numerous environmental-design publications over the last 25 years. $\mathrm{He}$ is currently Managing Editor of Traditional Dwellings and Settlements Review (TDSR), the journal of the International Association for the Study of Traditional Environments (IASTE), with which he has been affiliated since its founding in 1988. He has played a major role in planning and producing many of the edited volumes that have emerged from conferences and other initiatives of the Association since its inception. I Ie also scrved as Managing Editor of the journal, Places, from 2002 to 2009.

\section{The Contributors}

Gauri Bharat is Assistant Professor of Architecture at CEPT University in Ahmedabad, India. In both research and teaching, she is primarily intercsted in exploring how people engage with built environments. In teaching humanities and architectural research, she similarly focuses on exploring everyday life and crnvironments using discursive frameworks of popular culture, politics and marginality. She also practises with Analog Studio where they have designed and executed several private residences.

Anne-Marie Broudehoux is Associate Professor at the School of Design of the University of Quebec at Montreal, where she has been teaching since 2002. She is the author of Mega-Events and Urban Image Construction: Beying and Rio de Janeiro, published by Routledge in 2017. She has given several conference papers and published multiple articles on the socio-spatial impacts of large-scale urban transformations. Her book, The Making and Selling of Post-Mao Beijing, was awarded the International Planning History Society book prize in 2006.

Marvin Brown has been an architectural historian in the field of cultural resources management, primarily on the American East Coast, for 35 years. His study of Rosenwald Schools, built for African-American children in the South in the early twentieth century, received the Vernacular Architecture Forum's Buchanan Award for Excellence in Field Work in 2008. He served on the Board of Directors of the VAF for many years, edited its quarterly newsletter for a decade, and co-organized its 2016 national conference in North Carolina. I-Ic has written three books on that state's architecture. For the past 25 years, Marvin Brown has been a Senior Architectural Historian with AECOM and its predecessors in Raleigh, North Carolina. An AECOM assignment gave him the opportunity to encounter Richard Neutra and Ricardo Bordallo on Guam.

Tim Bunnell is Professor of Geography and the Deputy Head of the Department of Geography at the National University of Singapore. He also holds a joint appointment with the Asia Research Institute where he leads the Asian Urbanism Research Cluster. His research is focused on urban studies, urban aspirations, urban theory, and decentralized governance, specifically in Southeast Asia with a focus on Malaysia and Indonesia. He has authored many publications including books and journal articles, most significantly Malaysia, Modernity, and the Multimedia Super Corridor: A Critical Geography of Intelligent Landscapes (2004).

Tiago Castela is a Research Associate at the Centre for Social Studies of the University of Coimbra in Portugal. He has also recently served as Principal Investigator of the exploratory research project 'Urban Aspirations in Colonial/Postcolonial Mozambique' at the same centre. His research explores the history of the political dimension of spatial planning and architecture, with a focus on urban peripheries in southwestern Europe and southern Africa in the twentieth century.

Susanne Cowan is Assistant Professor of Architectural Yistory in the School of Architecture at Montana State University. Her research focuscs on the relationship between urban design and the social conditions of cities, particularly regarding participatory democracy as a method for urban policy-making. In her most recent work, she has been tracing the ways 
that planning policies in deindustrializing citics have shaped the process of urban decay and/or gentrification, and what positive or negative impacts urban design interventions have had on social and economic conditions of residents. Much of the research for her chapter took place in her former capacity as a Post-Doctoral Fellow at Washington University in St. Louis.

Lyndsey Deaton is a $\mathrm{PhD}$ candidate in architecture and the Associate Director of the Urban Design Lab in the School of Architecture and Allied Arts at the University of Oregon, Eugene. Her research explores how contemporary social phenomena, such as social media and neoliberalization, influence people's perception and use of the urban environment. She is a practising, licensed architect and urban designer and has completed projects across the United States as well as in Europe, the Middle and Far East, and Africa. Her most recent publications include a study of social cohesion in tiny house communities of homeless Americans published in a chapter in collaboration with Mark Gillem in Ethnographic Architecture, (2016) 'Security, Surveillance, and the New Landscapes of Migration'.

Jennifer Gaugler is a $\mathrm{PhD}$ candidate in architecture at the University of California, Berkeley. Wer rescarch focuses on the historic and contemporary architecture and urbanism of Rwanda and neighbouring countries in East Africa, including both vernacular building traditions and formal architectural projects. She is trained as an architect and has experience working in architecture in both the United States and Rwanda. She coordinated the 2014 IASTE conference, Whose Tradition?", in Kuala Lumpur.

Shu-Mei Huang is Assistant Professor at the Graduate Institute of Building and Planning, National Tawan University. Her rescarch interests include postcolonial urbanism, trans-nationalization of care and space, and dark heritage. She has carried out research into defunct prisons built by the colonial regimes in several East Asian cities, including Taipei, Seoul, Singapore and L, ushun. In collaboration with one of her Korcan colleagues, she is preparing for a book project on remembering of punishment in postcolonial Asian citics. She is author of Urbanizing Carssapes of Hong Kong: Tho Systems, One City (2015).

Abidin Kusno is Professor in the Institutc of Asian Research and Director of the Centre of Southeast Asia Research at the University of British
Columbia. His research examines the roles of cities in shaping the political cultures of decolonization, nation building, and development, with a particular focus on exploring the historical and contemporary conditions of urban politics and city life in Indonesia. Kusno has held multiple distinguished academic positions. He currently serves as the Canada Research Chair in Asian Urbanism and Culture at the University of British Columbia. He has authored several books, including After the New Order: Space, Politics, and Jakarta; Appearances of Memory: Mnemonic Practices of Architecture and Urban Form in Indonesia; and Behind the Postcolonial: Architecture, Urban Space and Political Cultures in Indonesia.

Ana Amélia de Paula Moura is an architect, $\mathrm{PhD}$ candidate at the University of Brasilia, and an Assistant Professor at Goiás Statc University. Her research focuses on modern architectural history and historic preservation.

Pedro Paulo Palazzo is an architect and Assistant Professor at the University of Brasilia School of Architecture. His primary research ficlds include the history and historiography of Brazilian art and architecture in the nineteenth and twentieth centuries; interactions between the classical tradition and the Modern Movement in monumental and civic architecture; and representations of architecture in painting.

Jayde Lin Roberts is a tenured Lecturer in Asian Studies at the University of Tasmania, Australia. She is an interdisciplinary scholar of the built environment and a Burma Studies specialist who was awarded a Fulbright US Scholar grant for 2016-2017. Her book, Mapping Chinese Rangoon: Place and Nation among the Sino-Bumese, was published in June 2016. Her current research focuses on discourses of development and urbanization in Yangon and Myanmar.

Mike Robinson is Professor and the Chair of Cultural Heritage at the University of Birmingham, UK, and is Director of the Ironbridge International Institute for Cultural Heritage. He is Founder and Editorin-Chief of the Joumal of Tourism and Culural Change and of the Tourism and Cultural Change Book Series. His work focuses on the relations between heritage, culture, and tourism, and he has published numerous books, articles and chapters on the various ways in which these realms collide. His recent research focuses upon conceptions of heritage in Taiwan and upon the heritage, tourism and collective memory relating to World War I. 
Dell Upton is Professor at the University of California, Los Angeles, where he tcaches courses on American and world architecture and urbanism, artand architectural-history theories and methods, material culture, and crossand architection formation in the postcolonial world. His books and articles treat subjects ranging from pre-Revolutionary American architecture to critiques of New Urbanism and heritage tourism. They include Another Citr: Urban Life and Urban Spaces in the New American Republic (2008), Architecture in the United States (1998), and Holy Things and Profane: Anglican Parish Churches in Colonial Virginia (1986). Upton served as a consultant and chief catalogue essayist for the Metropolitan Museum of Art's 2000 exhibition Art and the Empire City: New York, 1825-1861.

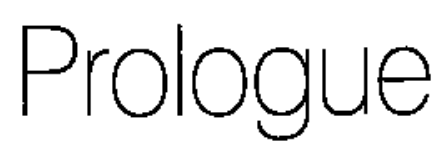


Noor, F.A. (2005) From Majapahit to Putrajaya: Searching for another Malaysia. Kuala Lumpur: Silverfish Books.

Ong. A. (1987) Spirits of Resistance and Capitalist Discipline. Albany, NY: SUNY Press.

Ong, A. (1996) Anthropology, China and modernities: the geopolitics of cultural knowledge, in Moore, H. (ed.) The Future of Anthropological Knowledge. London Routledge.

Powell, FE (1913) With Eastern Merchandise: A Landsman's Log on Board a Cargo Boat London: Thomas Murby and $\mathrm{Co}$.

Schottman, S. (2011) The Pillars of 'Mahathir's Islam': Mahathir Mohamad on being Muslim in the modern world. Asian Studies Review, 35(3), pp. 355-372.

Sham A. (1999) From Orang Kaya Baru to Melayu Baru: cultural construction of the Malay 'new rich', in Pinches, $M$. (ed.) Culture and Privilege in Capitalist Asia. London: Routledge, pp. 86-110.

Tan, S.B. (1992) Counterpoints in the performing arts of Malaysia, in Kahn, J.S. and Loh, F. (eds.) Fragmented Vision: Culture and Politics in Contemporary Malaysia, Sydney: Allen and Unwin, pp. 282-305

World Bank (1993) The East Asian Miracte: Economic Growth and Pubtic Policy. New York: Oxiord University Press

Yiftachel, $O$ and Ghanem, A. (2004) Understanding 'ethnocratic' regimes!' the politics of seizing contested territories. Poitical Geography, 23, pp, 647-676. 


\section{The Missing 'Brazilianness' of Nineteenth-Century Brazilian Art and Architecture}

\author{
Pedro Paulo Palazzo and Ana Amélia de Paula Moura
}

Despite their ideological opposition, Brazilian modernists and traditionalists in the early twentieth century had one stance in common: both agreed that the country's art and architecturc had, since the sccond half of the previous century, lacked national character and adaptation to Brazil's climate and social conditions. This postulate was partly refuted in Portuguese-language scholarship since the 1960s, which exposed the persistence of colonial-era patterns in the hinterland - and, in a few cases, in curban settings. Yet, in the drive to rehabilitate nineteenth-century Brazilian art and architecture, the actual discourses by which it came to be ostracized have themselves been suppressed from scholarship.

This chapter examines a few of the landmark narratives on the issuc of national character published between 1880 and 1940. The authors of these works are the acadcmic art critic Gonzaga Duque, the engineer and neocolonial advocate Ricardo Sevcro, the physician José Marianno Fillho, the Beaux-Arts architect Adolfo Morales de los Ríos Filho, the writer Monteiro Lobato, and the modernist architect Lucio Costa. Writings by these figures provided a variety of views of Brazilian character and the purported lack thereof in the art and architecture of the generations that preceded them. Yet, as the chapter will show, the aesthetic movements they werc affiliated with were actually less relevant to how each addressed this matter than thcir understanding of the nature of artistic endeavour and the building professions. And this, in turn, had much to do with their own social, racial, and regional backgrounds.
The late nineteenth and early twentieth centuries saw the decline of colonial and imperial plantation elites from northeast Brazil and the rise to power of coffee-growing and cattle-ranching oligarchies from the southeast, followed by the rise of industrial capitalism. Urban growth and renewal displayed eclectic styles of architecture, at least until the 1910s when the moralistic traditional or neocolonial movement began to set the tone for architectural debate.

\section{Assessing National Character}

The Brazilian cultural establishment, in the early twentieth century, took a keen interest in the matter of national character in art and architecture. This interest can be traced to two concurrent influences: the nation-building debates spearheaded by the Brazilian Historical and Geographic Institute (IFGB), beginning in the 1840s, and the nationalistic themes of European romanticism. A landmark in the first instance was the publication, in 1854, of Francisco Adolfo de Varnhagen's História Geral do Brasil (General History of Brazil), which defined the Brazilian nation as the junction of three races: the white Portuguese, black African, and Amerindian. Nationalistic romanticism, meanwhile, had its most acclaimed expression in the literary movement known as Indianism, which was later picked up in painting, as in Rodolfo Amoedo's (1857-1941) series of Indianist works from the 1880s. But in historiography as well as literature and art, Indianism portrayed the South American native more as an allegorical icon than a true actor in the formation of the Brazilian nation. Agency, and especially intellectual agency, was still a concept reserved for the white ruling elite of ancestral Portuguese descent, while black Africans were regarded as mere menial labour without any role in the making of Brazilian culture. This view of native people was evident in Amoedo's masterpicce, The Last Tamoyo (1883), in which the Indian's death, historically placed in 1567, is symbolic of the onset of European rule (figure 8.1)

Around the same time, the young art critic Luiz Gonzaga Duque Estrada (1863-1911) worried, paradoxically, about the disappearance of national character in art. In the book that provided a synthesis of his early thinking, A Arte Brasileira (Brazilian Art) (1888), he gave a pessimistic account of his subject matter:

The novels, history, and poetry of this country had no influence whatsoever in these works, which remained impervious to the dawn of national thought... 


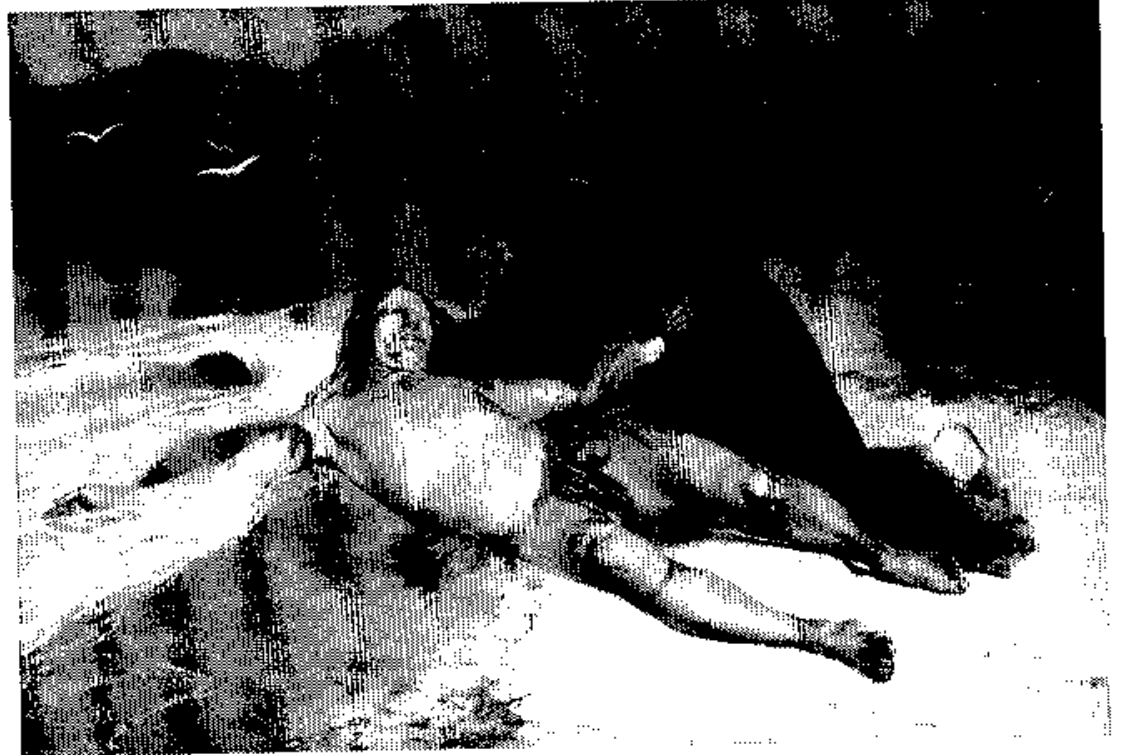

Figure 8.1. Rodolfo Amoedo, The Last Tamoyo, 1883

One concludes, then, that this art is missing native features and originality, primordial qualities for the founding of a School.

The defining feature of our art is cosmopolitanism, and a nation, to have a School, needs, formost, a national art. (Gonzaga Duque Estrada, 1995, pp. 258-59)

As a critic, Gonzaga Duque was not the least impressed by earlier art. Even the monumental architecture of the colonial period (1530-1808), which so captivated later writers, was to him 'a flagrant cvidence of bad taste and lack of intelligence' (Gonzaga Duque Estrada, 1995, p. 74). To their credit, he conceded, painters such as Manoel da Cunha (1737-1809) had, at least, a sort of crafty authenticity about them (Gonzaga Duque Estrada, 1995, p. 81). But national character was not to be extracted from the achievements of previous eras, as was the view among European romantics; it was something yet to be produced out of the maturing of latenineteenth-century artists. Neither was it to be found in any spccific style, but in the choice of proper subject matter, chiefly Indians (Gonzaga Duque Estrada, 1995, p. 185).

Later on, however, in 1909, an aging Gonzaga Duque would soften his views and commend Amoedo for having outgrown Indianism, 'vanquished by the assimilating force of a superior environment' (Gonzaga Duque Estrada, 1929, p. 13). That 'superior environment', of course, was European academic culture, in the form of classical nudes and mythological scenes. And in his last survey of Brazilian art, the opening speech at the 1908 Salon in Rio de Janeiro, he summarized a triumphal picture of national art:

The characteristic art, truly Brazilian, shall appear from this admirable nature, from this golden light, from this popular soul made of the Indian's nostalgia, the animal infallibility of the African, and the lyrical soul of the uprooted, seafaring Portuguese. (Gonzaga Duque Estrada, 1929, p. 255)

Thus, by this time, Gonzaga Duque no longer saw European influence as harming the expression of national character. On the contrary, it would provide the necessary professional expertise and cultural environment in which national character would gradually emergc. The colonial heritage, of Portugucse and Catholic extraction, was the mythical ancestor of contemporary national character. It was a 'historical document' of utmost importance, one to which ritual deference was owed. Yet it was also one that should exert minimal influence on contemporary conceptions of national art (Gonzaga Duque Estrada, 1929, p. 247). This positive, yet condescending, notion of colonial art would be picked up a few years later by the first Brazilian traditionalists as a means of reconciling tradition with modernization.

\section{Tradition and Decay}

The years leading from the restructuring of the federal debt in 1902 to the national exposition of 1908 witnessed a build-up of momentum for pairs of conflicting urges: cosmopolitanism and the expression of national character; exaltation of modernity and industrialization and the taste for exuberant tropical nature; political centralization and regionalism (Pereira, 2011). In keeping with the romantic nationalist drive that first established the debate on national character, Brazil was seen as having started off under the yoke of Portuguese culture, but then slowly differentiating herself under the influence of climate and land. To this way of thinking, a national character in art and architecture was an optimistic prospect rather than something already achieved at any point in the past or present. This placement of national character in the future was a boon, in the first quarter of the twentieth century, for authors and movements claiming to construct Brazilianness. And where Gonzaga Duque forecast a natural, unconscious development of a Brazilian art school, other writcrs laid out actual programmes to create this national style. 
Around the time of Gonzaga Duque's passing in Rio, a sharp critical and literary scene was also emerging in São Paulo. One of the most prolific writers, addressing the issue of national character both explicitly and implicitly in this milieu, was José Bento Monteiro Lobato (1882-1948). His debut work of fiction, Unupês (1918), was an attack on the agrarian society that had once dominated national politics, and that he viewed as socially and culturally decrepit. The closing chapter of Unupês featured an unforgiving criticism of the literary infatuation with this old-fashioned culture. Monteiro Lobato was, like many of his fellow intellcctuals from São Paulo, an outspoken enthusiast of material progress and industrialization. The juxtaposition of unrelated anecdotes from remote towns was a literary device used at the time to create contrast with the conventional and uneventful ways of life typically portrayed in literature. On the one hand, it exacerbated the naturalistic tendency towards depicting individual scenes; yet, on the other, it refused to condone the idealized image of country folk as authentic representatives of the national character (Silva, 2013, p. 303). Indeed, in the 1910s, the icon of rural culture was the caipira, Brazil's version of a country bumpkin sunk into cndemic poverty, who had recently replaced the Indian as a favourite literary character (Monteiro Lobato, 1944, pp. 208-209)

Monteiro Lobato's criticism of the inert social and material underdevelopment of small inland towns in Cidades Mortas (Dead Cities) (1919) was, however, more complex than such images might make it appear. The pretentious self-sufficiency of the establishment in the aptly named fictional city of Oblivion, for instance, alluded to a sort of timeless decrepitude, rather than mere underdevelopment. ${ }^{1}$ People in Oblivion died of boredom, not material want (Monteiro Lobato, 1919, p. 5). And the dead towns contained: 'impressions of a dead youth that vegetated in the stagnation of the dead cities. There is also some modern stuff. But both modern and old are wortly the same - nothing' (Monteiro Lobato, 1919, epigram).

This sense of hopclessness, of something that would have been yct did not bear fruit, struck a strong chord with Monteiro Lobato's contemporaries, as it clearly alluded to the material and moral decadence of once-thriving urban centrcs in the depleted coffee-growing regions in upstate São Paulo (Silva, 2013, p. 299). Thus, according to Monteiro Lobato $(1919$, p. 8$)$ :

There, everything was, nothing is. No verbs are conjugated in the present tense Everything is preterit,
A group of dying cities drag on a decrepit living, spent weeping in today's pettiness the nostalgic greatness of yore.

Monteiro Lobato rejected the romantic and naturalistic ideal of glorifying a national (or even regional) character, embodied in traditional society. His fiction - and his political activism - were thus at odds with rural oligarchies of colonial Portuguese descent. These oligarchies had, up to this time, claimed to be the true makers of high culture and had been prominently portrayed as nation-builders in Indianist literature and art. Yet, in contrast, Monteiro Lobato represented the aspirations of emerging urban industrialists who rejected the lingering dominance of this decadent rural elite. This rivalry was all the more evident in the cosmopolitan, eclectic architecture favoured within São Paulo city, as opposed to the persistence of Neoclassicism upstate.

Nevertheless, Cidades Montas evidenced a different sort of nostalgia, harking back to Gonzaga Duque's early writing. The idea bere was that some process of national character-building had been underway, crude but authentic, but that it had been stifled before reaching cultural maturity This was thus a construction of a mythical 'time outside time' (Eliade, 1966). And, built on the sense of eternal decay from an acme that never was, it set the stage for the elaboration of a highly malleable image of lost Brazilianness. Crucial to this narrative of mythical loss (of something that never existed) was the implicitly perceived gap retaining a tenuous link to chronological continuity (Silva, 2012, p. 293). It would have been clear to Monteiro Lobato's readers that decay in the region of the dead cities set in around the 1860 s, and had begun to be feit more strongly after the 1880 s, when the early coffee-growing lands were becoming depleted and fledgling industries were being set up with the arrival of the railway in São Paulo city.

\section{Reconstructing Brazilianness}

Monteiro Lobato saw in material and cultural modernization the only means of escape from this eternal decay. To him, the heyday of the coffeengrowing urban society was little more than an abstract backdrop for criticizing the backwardness of traditional clites. Meanwhile, in São Paulo, the Portuguese engineer, archaeologist, and republican activist Ricardo Severo was promoting similar ideas about a stifled development of national character followed by a period of decay and the need to reassert the greatness of Brazilian identity. Severo's position can be seen to coincide with the development, in the early twentieth century, of traditionalist 


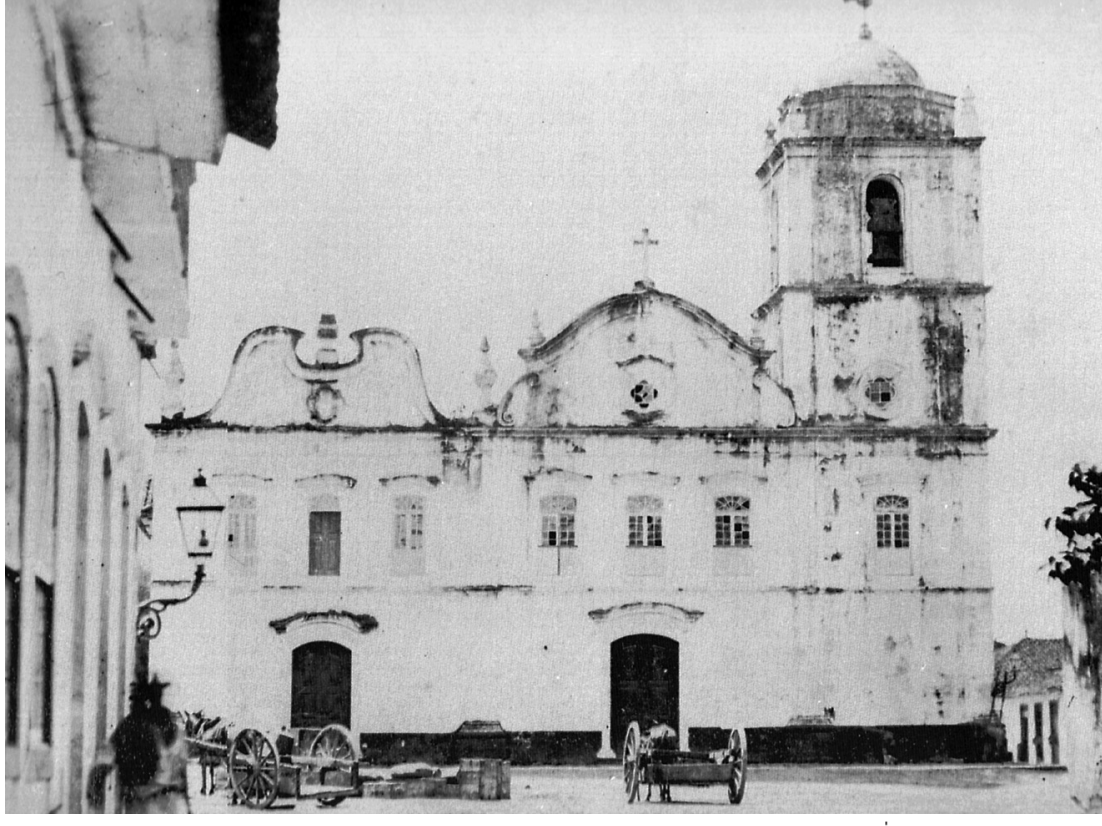
wait patiently for a national school to emerge spontaneously. He outlined, instead, a programme to give Brazilian architecture a distinctive character right away. As Azevedo (1994, p. 249) has pointed out, Severo argued that the forms and plans implanted in the Americas by Portugucse colonists, chiefly derived from both Roman and Moorish sources, were to be the basis for the establishment of a national-traditional art in Brazil.

The Portuguese always gave a particular mark to the architecture he imported, and this phenomenon, noted by the most illustrious historians of Portuguese art, shows up in colonial Brazil as well, where the Baroque, said to be Jesuitic, took on expressions of modest simplicity, but with a noteworthy local mark. (Severo, 1917, p. 402)

Severo made a point of showing how colonial houses and churches, such as the parish church of the Rosary in Santos, displayed exactly that sort of plainness (figure 8.2). '[B] eing appropriated into the local setting and in their aspect of characteristic originality', this would constitute 'what is or may come to be 'rraditional Architecture [his capitals]' in Brazil. And he proceeded to decry the arrival of fresh immigrants at that time - 'deft stuccoists come from Italy and Portugal' who brought a 'façadist' habit of making up 'incomprehensible styles that shocked mostly by their disconnection with the local setting and its destination' (Severo, 1917, p. 415). The 'solution, he asserted, was to reclaim an authentic national tradition, consisting of the adaptation of old Portuguese styles (which cren his fellow countrymen had abandoned) as transformed by the influence of local climate and geography.

Indecd, as a recent Portuguese immigrant, Severo was at odds with two groups who sought to establish their own narratives of architectural tradition. One was the aforementioned rural oligarchies against which 1908). (Photo: Milităo Augusto de Azevedo, 1865)

Monteiro Lobato rose; the other was a diverse class of skilled immigrants of various nationalities, among whom were several architects and their patrons, who introduced eclecticism to Brazil's major cities. Severo, therefore, set out to uphold traditional Portuguese architecture, which he had studied at length in his youth, against both the sophisticated cultural Portuguese roots to embrace French neoclassicism), and from the eclectic architecture of European immigrants, which was unrelated to local history and climate

The argument constructed by Severo then rested on the ideal of a national character consisting in a timeless, natural Portuguese adaptation to the South American genitus loci. This had been suppressed by unfortunate eclectic influence in the second half of the nineteenth century. This was the same idea of a cycle of timeless authenticity followed by a historical Monteiro Lobato's 'dead cities'. Yet where the fiction writer had a much more negative view of rural society, the Portuguese engineer was careful not to romanticize old houses, cspecially inasmuch as they were the abodes of the landed clite, who had also been partly responsible for the recent degeneration. He made his case for material and even aesthetic progress, if only tempered by traditional adaptation to the site:

Traditional Architecture does not mean, then, literai reproduction of traditional things, of archaeological fossils, of rammied earth or cob houses, of little adobe churches, of alleys
Figure 8.2. Our Lady of the Rosary parish church, Santos (dedicated 1754, demolished tradition of the rural Brazilian elites (who had departed from their gap fostering decadence which would be represented 2 years later in 
between shacks three fathoms deep, with door and louvered window, or of the gloomy houses in the city centres of yore, without hygiene or aesthetic appeal.

Traditional art is the stylization of earlier artistic forms that constitute at some point in time Traditional art is the stylzation of earal character of a people, the hallmark of its civilization; it is the product of a rhythmic evolution of successive cycles of art and style... (Severo, 1917. pp. 423-424)

\section{Modernity and Preservation}

Severo wrote, spoke, and designed in São Paulo - a city that, betwecn the late eighteenth century and the 1860 s, had been almost as 'dead', economically and architecturally, as Montciro Lobato's fictional cities. Little of any significance had been built there between the reconstruction of the emblematic Jesuit College, in 1700 , and the opening of the railways, in $1867-1871$ (Lemos, 1987, p. 72). Rio de Janciro, in contrast, was in the 1910 s the nation's capital, twice as large as São Paulo, with a much more diverse architectural heritage. Moreover, it had undergone a continuous process of urban infill and extension throughout the ninetecnth century, with a self-conscious interest in up-to-date architecture, crowned by the with a self-conscious interest in up-to-dale renewal of its core, starting in 1902. The differences between traditionalist discourse in São Paulo and Rio are therefore not surprising.

In the capital, José Marianno Carneiro da Cunha Filho (1881-1946),

a hygienist physician and amateur architcet, was the chicf advocate of the traditionalist movement, to which he gave the name 'neocolonial' (Kessel, 2008, p. 132). Marianno was also instrumental in rousing public support for monumental buildings to be designed in the neocolonial style, in addition monumental buildings to be designed in the neocolonial ster architectural compctitions biased toward the same stylc. Josć Marianno Filho's family belonged to the old northeast landed elite, having owned plantations there since the colonial period. It was also a highly cultured family; during the mid-twentieth century alone, it had contributed three members to the forty-seat Brazilian Academy of Letters (among them Marianno's own brother, the poet Olegário Marianno.)

Because the colonial architecture of Rio had been heavily affected by later development, traditionalists in the capital had to look elsewhere for documentation. Former gold-mining towns such as Ouro Preto and Diamantina - now both World Heritage sites - were, conversely, their ideal image of a traditional urban culture, supposedly frozen in time up to the day twentieth-century critics 'rediscovered' them (figure 8.3 ).

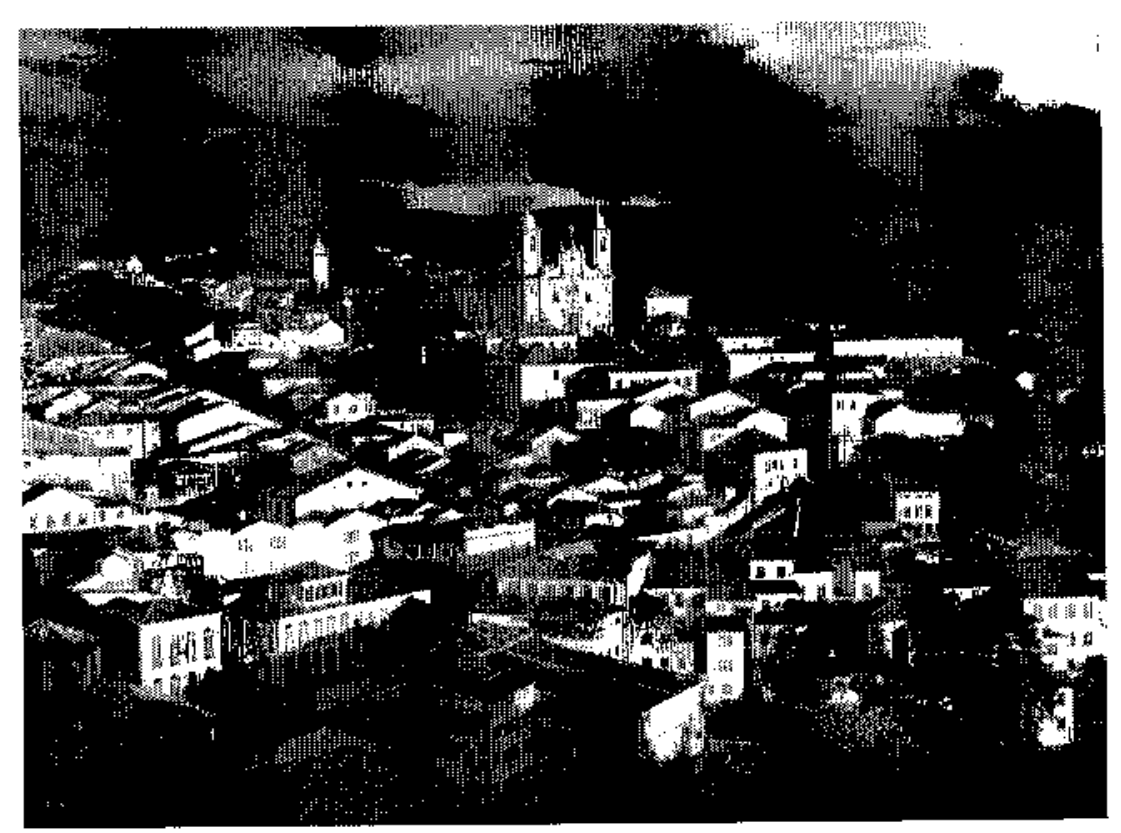

Figure 8.3. Panoramic view of Ouro Preto. (Photo: Pedro Paulo Palazzo, 2010)

The picture Marianno drew in 1943 of this inland architectural tradition was onc that gave all the laurels to his own colonial forebears at the expense of every other group in modern Brazil. Spccifically, there was no place in it for South American Indians, nor for influences from Portuguese architecture after the end of the colonial period. And, although the sociologist Gilberto Freyre (1900-1987) had published, 10 years earlier, The Masters and the Slaves (a dense account of Africans' ubiquitous role in shaping Brazilian culture), they, too, were absent from Marianno's narrative. His lone hero was the weathered Portuguese explorer, barely stepping out of the Middle Ages and of Arab domination to exert his nononsense creativity on a virtually virgin new world:

The Portuguese colonist, old friend of the sun, brought to the Brazilian land the centuriesold experience of his race, drawn out of the contact with the oriental civilizations, and learned above all from the Moorish experience. Thus, in confronting the Brazilian architectural problem, the Portuguese colonist had not the slightest hesitation... During the first two centuries of national life [the sixteenth and seventeenth centuries]. Portuguese architecture was imperceptibly adjusting itself to the Brazilian way of life... The absence of classical elements, together with the lack of a properly skilled workforce. led the people to improvise new practices and processes, unknown in Portugal, (Marianno Filho, 1943, p. 10) ${ }^{3}$ 
Marianno's national tradition, even more so than Severo's, hinged on the notion of the self-sufficiency of the Portuguese colonist vis-à-vis the other ethnic groups that made up Brazilian society - as well as of more recent Portuguese immigrants. For him, "the preference of man for the architecture of his homeland' had an emotional source, based on domestic reminiscence and unconscious references. He therefore deplored the newly arrived Portuguese immigrants who, "instead of proceeding like the Italians, British, or Germans, who favour the styles of their own nations .. scek intently to hide or mask their own' (Marianno Filho, 1943, p. 32). 'This hiding of the national style, in 1943, could be applied both to the immigrants' eclecticism and to the characterless and 'stateless styles' of modern architecture, championed by scveral young Brazilian architcets. Marianno bemoaned the modernist mentality, which, in seeking to abolish the principle of decor, reduced 'the art of building to the science of making housing', rcquiring mere efficiency and economy (Marianno Filho, 1943, p. 15).

This dispute had consequences for the new prescrvationist mindsct that was taking shape in Brazil at the time. This view regarded historic preservation as the same as the antiquarian conservation of 'archaeological fossils'. And it emphasized instead that a living tradition had no need for physical vestiges of the past, only for its documented knowledge. However, documentation proved selective. And even Severo gave in to the contemporary taste for modern plans and massing (Mello, 2007, p. 178). Thus, late in life, probably after secing many of his 'documents' disappear bencath the march of progress, Severo commissioned the painter José Wasth Rodrigucs (1891-1957) to make a comprehensive study composed almost entirely of details. This was published in instalments, but only after Scvero's death (Rodrigucs, 1975).

For his part, Marianno, who was not a regularly practising architect (and thus took no notice of the public's architectural taste) wanted the documentation of traditional architecture to yield different results - but with the same disregard for physical conservation:

do not care for the plastic qualities of traditional Brazilian architecture, because what I seek in it is far above these qualities... Less of an artist than a sociologist myself: consider architecture to be the social instrument of nationality. I do not care for artistic virtues, the charm of lines, or the splendour of details; by means of which the architectural styles are expressed. What 1 seek are the organic qualities, the healthy virtues, the structural fundamentals, from which stem the perfect accord of architectural feeling with the nation's soul. (Marianno Filho, 1943, pi 64)
For both Severo's and Marianno's purpose, the perennial preservation of old buildings was inconsequential; the knowledge extracted from their documentation was all that was needed to revive tradition. Severo thus celebrated the reconstruction of the São Paulo Law School by the firm Ramos de Azevedo in 1930-1934, which replaced a seventeenth-century rammed-earth monastery with a neocolonial concrete building (figure 8.4), Modern materials and technologies were welcomed in this endeavour to forge a new Brazilian architecture that was to remain abstractly grounded in deeper principles, respecting its ancestral 'Roman spirit, characterized by the constant proportion of its compositional elements, and by its rectangular geometric projection' (Marianno Filho, 1943, p. 124).

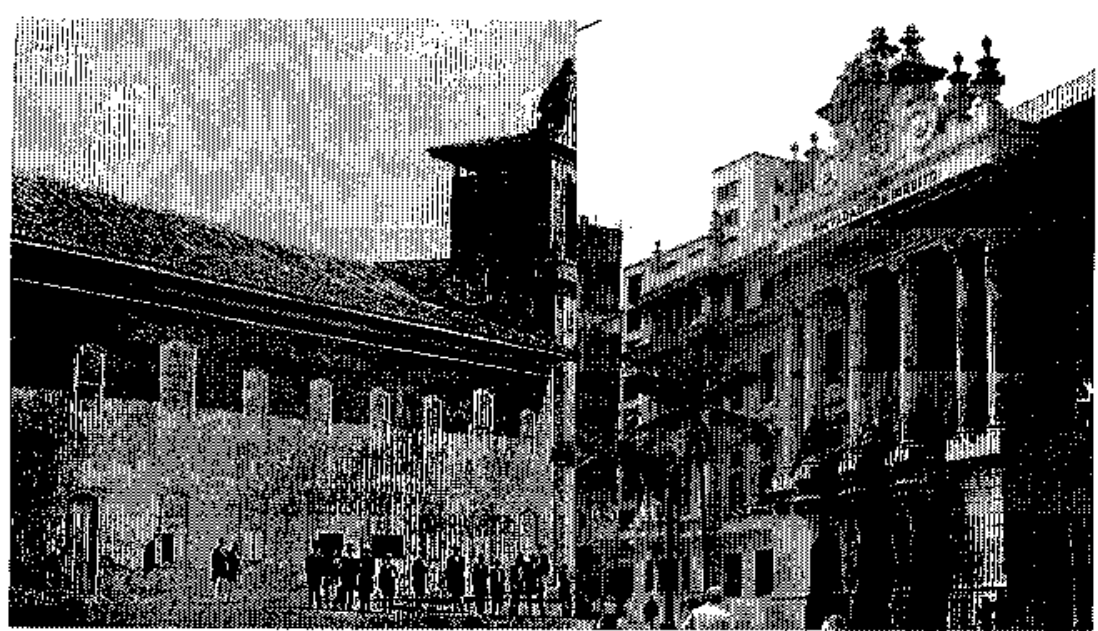

Flgure 8.4. Left: The Franciscan monastery dedicated in 1654. (Photo: Militāo Augusto de Azevedo, 1862) Right: Săo Paulo Law School, which replaced the monastery, (Photo: Pedro Paulo Palazzo, 2007)

This ideal of material progress rooted in social conservatism was echoed in the writings of the young architect Lucio Marçal Ferreira Ribeiro Lima Costa (1902-1998). Lucio Costa is nowadays best known for the modernist design of Brasilia (1957), but during the 1920s he was a neocolonial practitioner under Marianno's wing. In 1929, he argued against the example of the exceptional monumental buildings of Brazilian Rococo. Following the views of his patron, Costa held that it was instead the simple architecture of anonymous mastcr builders that embodied the functional, technical, and aesthetic homogeneity of Brazilianness (Puppi, 1998, p. 22). After Costa's conversion to modernism, he authored an article in 1937 describing what he held to be the natural development of traditional 
Brazilian architecture. True to his roots, he was speaking of residential architecture, built by masons and carpenters, which remained impervious to:

the unforeseen development of bad architecture teaching - giving future architects a whole, confused 'technical-decorative' education, with no link whatsoever with life, and not explaining them the why of each element, nor the deep reasons that conditioned, in each period, the appearance of common features, that is, of a style... (Costa. 2007 c, p. 93 )

Because Costa did not focus his narrative on learned architecture, as ate 1910 he was able to circumvent the problem of 'bad teaching' and late as 1910 he was able to circumvent the problem of bad tcaching and argue for the survival of an authentic thadith onset of the traditional architecture movement (to which he had previously belonged) and which he later condemned. This opposition notwithstanding, all elements of the post-romantic nationalist narrative were represented in his text: an original period of authentic national character followed by another of pretentious decay; the possibility of overcoming that decay by promoting a certain architectural movement; and the defence of technical modernization and aesthetic advance while remaining anchored in that authentic national tradition. A few years later, though, Lucio Costa drifted from the broad sociological picture of national character to a romantic view, which favoured individual artistic intent (Costa, 2007b, p. 113) and personal genius (Costa, 2007 a p. 125), both cmbodied in his friend, Oscar Nicmeycr (1907-2012).

Although Costa put forward the thesis of a chain of authentic architecture broken only by the neocolonial movement, his practice as preservation official effectively upheld Marianno's view that proper Brazilian architectural tradition did not reach far beyond 1800. In practice, though, dating often relied on conventional wisdom about local history as well as a priori assumptions about pre-ninetcenth-century styles, since historical documentation was still sparse (Pinheiro, 2012, p. 25). Proof of this uncertainty was that typological studies of colonial buildings published in the SPHAN (National Historic and Artistic Heritage) journal during the 1930s and 1940s (one of which was penned by Lucio Costa himself) were unable to ascribe even so little as rough date ranges to buildings or styles.

This view, both partisan and clouded, entailcd questionable choices cven for those buildings meant to be preserved. A number of supposed neoclassical or eclectic accretions to historic churches were thus carelessly replaced with modern re-creations of that original 'simplicity' heralded by

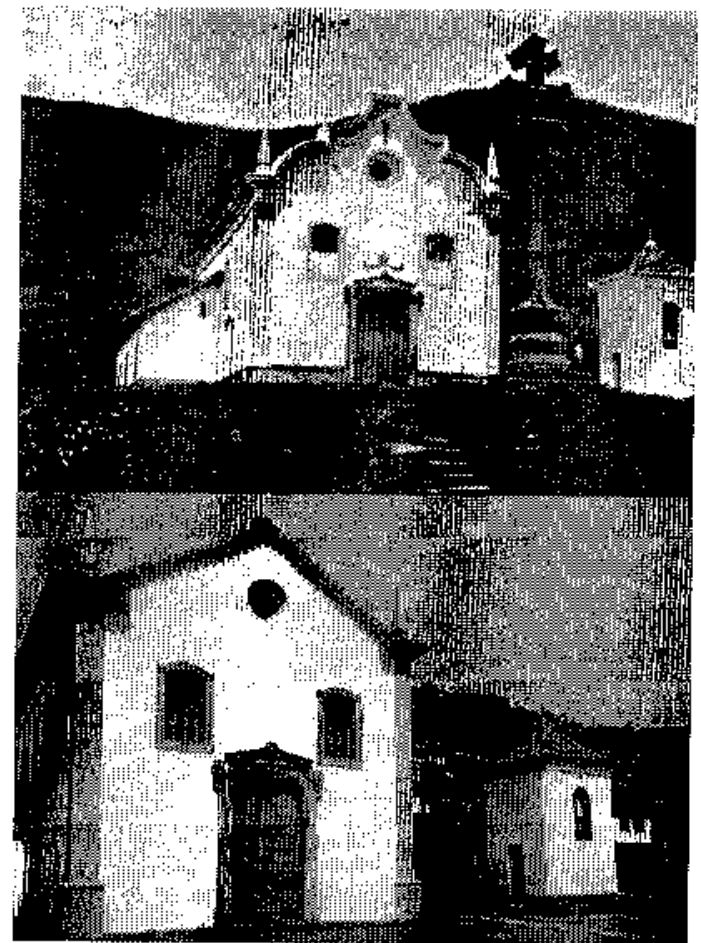

the neocolonial architects (Pinheiro, 2012, p. 238). One example was the Chapel of Padre Faria in Ouro Preto (1936-1937) (figure 8.5). Meanwhile, in São Paulo, campaniles were stripped of their spires and entire wings in farmhouses were removed, in an infatuation with the ideal of volumetric simplicity promoted by Marianno and Costa (Mayumi, 2008, p. 61). As part of this programme, elcments that seemed to prefigure modern architecture werc particularly favoured, while the chronological uncertainty of the vestiges was ideologically interpreted as timeless wisdom:

Colonial constructive devices, such as buildings on stilts, trellised louvers, and cob on wooden frames, were associated with pilotis, brise-soleils, and reintorced concrete. For modernist architects, the resemblance between their own architecture and the colonial one was not one of appearance or effect, as was the case in Neocolonial buildings, but one of structure. (Fonseca, 2005, p. 188)

\section{Tradition and the Professional Architect}

The onsct of the Modern Movement in Brazilian architecture thus entailed a power struggle between the proponents of the neocolonial movement 
and their younger rivals. Both camps deployed the same narrative about the development of national character in order to promote opposing views of architectural style and space, and both derided their rivals as being so beneath them as to make 'non-architecture'. In the meantime, a single, dissonant chord struck the debate in Rio: Adolfo Morales de los Ríos Filho's book Grandjean de Montigny $e$ a evoluçâo da arte brasileira (Grandjean de Montigny and the Evolution of Brazilian Ant) (1941). In this work, Morales de los Ríos (1887-1973), then director of the National Fine Arts School, celcbratcd the school's founder and the first French architect to have worked in Brazil, Auguste Henri Victor Grandjean de Montigny (17761850). The book harked back to Gonzaga Duque's positive view in his later years of European influence on Brazilian art:

Yes, it dignified Brazilian art, fighting the neglect and ignorance of a fledgling society and contributing to the foundation of an art school, where it would have been difficult to create it using existing [local] resources. (Morales de los Rios Filho, 1941, p. 157)

Morales de los Ríos had a personal axe to grind as well. The Bcaux-Arts method had been under critical firc for well over two decades, first from the traditionalists, then from the modernists. Morales himself, the son of a Spanish eclectic architect, was the embodiment of the non-Portuguese, noncolonial practitioner that Severo, Marianno, and Costa collectively decried. The National Fine Arts School was somewhat open, nevertheless, to the teaching of neocolonial architecture in the 1920s, although it was but one of several eclectic styles used and mixed by students and teachers. Moreover, urban renewal in Rio, stepped up since 1920, was threatening the ninetecnth-century eclectic heritage just as much as it had disfigured the monuments of the colonial period.

Morales de los Rios's arguments, howcver, were of a different nature from those of the neocolonial and modernist groups. Unlike thesc, he was directly implicated in the education of a class of elite artists, expected to succeed in both public and private commissions. Thus, he defended not only the historical roots of his school, but also the diversity and adaptability of architects in a time of rapidly changing tastes among the public - particularly at a moment when support for neocolonial-styled public buildings had all but disappearcd. Also, the fascist government led by Getúlio Vargas (1930-1945) no longer sought the example of the other American republics, preferring that of Italy, in politics as well as in art and culture. Public architecture in the Vargas regime oscillated between the stripped classicism, then popular in most European countries, and modernism, which was half-heartedly supported by fascist Italy at the same time. As for the fickle bourgeois of São Paulo, they moved on to favour aestheticist variations of Art Deco, Italian rationalism, and whitewashed modernism.

In opposition to this, both Ricardo Severo and José Marianno Filho had advocated a sort of sociological collectivism in the architectural profession. Severo, a republican activist who, at first, moved to Brazil to avoid political persecution in late-monarchical Portugal, expected architecture and architects to play a role in the forging of a modern - meaning nationalist state, conscious and proud of its ethnic origins (Mello, 2007, p. 29). Severo sought to balance his archaeological interests, which led him to favour a structuralist cohesion of sorts between a centuries-old culture and its present developments, and his practice as an architect, where he ultimately gave in to public expectations of wholly modernized, eclectic plans and picturesque massing. Neverthcless, he was successful in fostering public taste for such traditional Brazilian elements as seventeenth-century alpendres (deep and wide colomnaded porches) and gencrous roof overhangs. These features went on to become favourites of Brazilian single-family houses throughout the twentieth century.

As for Marianno, a scion of the landed elite from the Brazilian northeast, architecture was a dilettante passion as much as a political cause. Free from the need to make a living out of the trade, he had little interest in matters of professional cohesion and the construction industry. Conversely, with his disposable income, he was able to fund documentation projects, as well as publicity stunts in the form of design competitions. He was also a regular contributor to the press throughout the 1930s. As state support for neocolonial architecture waned during that decade, his criticism of the Modern Movement increasingly resorted to the sort of political slander expected to appeal to the heads of the fascist government. Architectural Judaism' and 'Communist architecture' were expressions used in his later writings (Marianno Filho, 1943, p. 41). And he compounded these with attacks on artistic 'freemasonry' that were appealing to a conservative, Catholic public

Because of his early years in the neocolonial movement, and in reaction to Marianno's criticism of Modern architecture, Lucio Costa, too, resorted to an cthnic narrative about the roots of national artistic character. Thanks to a few years spent in France during his youth, he had come into contact with the architectural and political aspects of racial discourses. Morcover, as soon as he became a heritage official, he was free from the concern of day-to-day professional practice. 


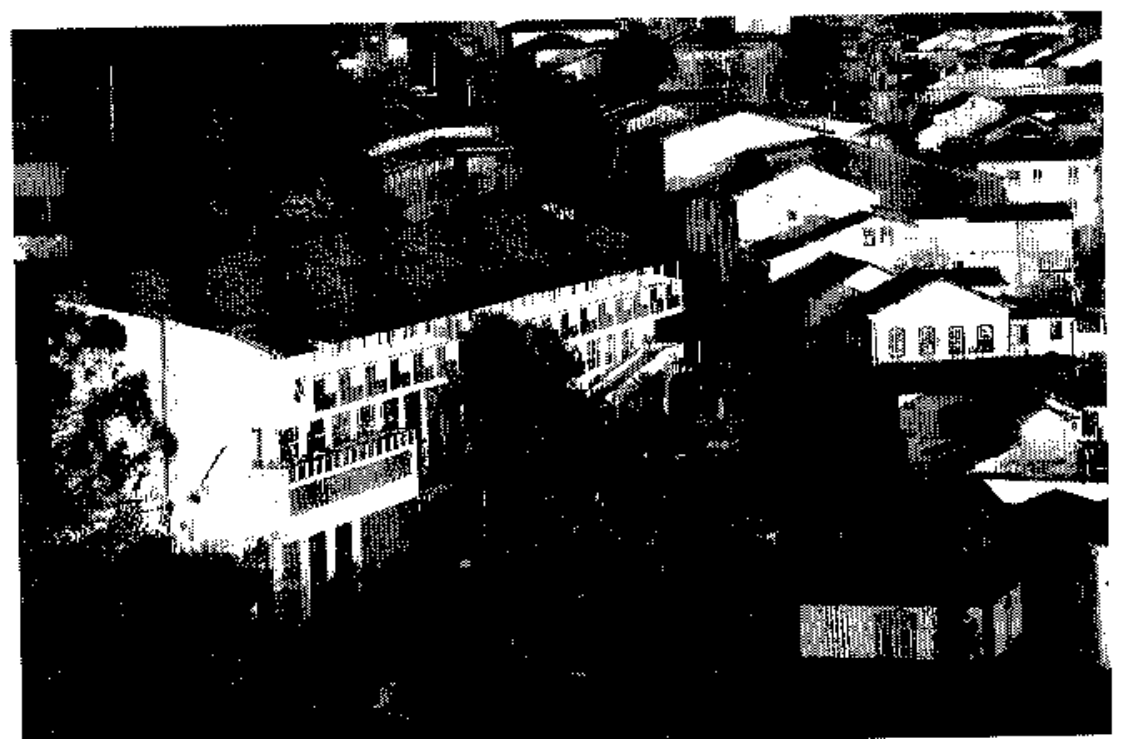

Figure 8.6. Oscar Niemeyer, Grand Hotel Ouro Preto, 1939-1944. (Photo: Pedro Paulo Palazzo, 2007)

Costa at first supported Marianno's narrative of a collective, anonymous architecture - even through his first decade as a leader of the Modern Movement in Brazil. And this led bim to shum, initially, the few known masters of Brazilian art in the colonial period. But by 1945 his writings focused chiefly on self-conscious artistic intent and the importance of individual gensis for the development of stylle. A hinge noment in his vicws probably occurred around 1939, when he supported Oscar Niemeycr's attempt to insert a modernist hotel at the heart of the historic district in Ouro Preto (figure 8.6). Costa then moved away from the ethnological understanding of architectural coherence, to argue that an architectural work of art 'shall not resent the proximity to other works of art' (quoted in Comas, 2010). Throughout the remainder of his long writing career, he strove to reconcile both vicws, as the discourses on the artistic originality of the Modern Movement became hegemonic. The unchallenged cthos of national genius that Costa helped construct for Niemeyer remains to this day a favourite topic of debate on the nature of professional practice in Brazilian architecture.

\section{Against the 'Weakness' of Brazilian Culture}

Despite their differences, Gonzaga Duque, Montciro Lobato, Ricardo Severo, José Marianno Filho, and Lucio Costa constructed and upheld a long-lived teleological history of Brazilian art. It was fuelled by a nationalistic spirit, raised against what they considered to be weaknesses in Brazilian culture. The starting point of this narrative was invariably a timeless period of formation of the national identity, followed by a clearly circumscribed period of decay. The starting point did not need to be an exemplary or admirable stage. The essential point was that it provided fundamentals of national identity that could be later reworked and improved: Portuguese language and way of life, adaptation to climate and geography, simplicity, and rationality. Yet the contribution of South Amcrican Indians and enslaved Africans was entirely disregarded, despitc growing evidence of their fundamental role in shaping Brazilian culturc.

Disagreements among these authors revolved mostly around which social group claimed the atthority to define national character and, therefore, whose tradition was to be held up as the true architectural inage of Brazil. Gonzaga Duque, at the dawn of the twentieth century, wanted the artists themselves to take the lead; in this, he was followed three decades later by Adolfo Morales de los Ríos Filho. Although Monteiro Lolatio did not promote any architectural style, he outspokenly condenumed the decrepit tradition of old-fashioned rural society. It was this very rulril tradition, of colonial origins, that was, on the other hand, Jose Millimmon Filho's model of Brazilianness, to be resurrected by means of architurturt. Ricardo Severo clained a middle ground between the latter two intlins, disparaging the architectural decadence in contemporary Britril while upholding the authority of Portugucse tradition as represented in the rustic colonial architecture of São Paulo. Lucio Costa, a former necocolonial practitioner converted to modernism, emphasized the practicality of colonial builders and the simplicity of their forms - so much so that several later historians of Brazilian architecture, acting perhaps out of moral reverence for their predecessor, ascribed this quality of simplicity even to the most ornate of colonial monuments (Campcllo, 2001).

This shunning of nineteenth-century art had strong consequences for Brazilian architectural historiography. The colonial period had been little known until the documentation efforts of the traditionalists, but vernacular architecture of the nineteenth century remained poorly studied throughout most of the twenticth century. While the high art of the same period survived, several important buildings werc allowed to be destroyed because they did not fit into the continuous march of national character through history.

Nevertheless, research on ninetcenth-century art and architecture has flourished in Brazil over the past two decades, and the writings of Monteiro 
Lobato, Severo, and Marianno have been reappraised as important historical documents. Incidentally, this has led to an unfortunate reaction, one which has portrayed the period between 1930 and 1990 as a dark valley in Brazilian architectural historiography (Puppi, 1998). Meanwhile, the contributions of Gonzaga Duque and Morales de los Ríos Filho to the study of Brazilian art have yet to receive major scholarly attention, probably because they do not fit into the broad teleological theses that have been the favoured subjects of recent historical revisions.

\section{Notes}

1. The name 'Oblivion' appears in English in the original.

2. These and other inland settlements from the mid-eighteenth century were, of course, later found not to have been 'frozen' at all after the end of the gold rush, nor to have been representative of colonial architecture as a whole. Furthermore, they retained a living, literate culture that preserved narratives from local history, which went largely ignored in the capital.

3. The acknowledgment of a 'Moorish' background was popular with the hygienist community at the time, due to the belief that the Arabs had introduced urban sanitation to medieval Europe.

\section{References}

Amaral, A.A. (1994) Arquitectura neocolonial: América Latina, Caribe, Estados Unidos. São Paulo: Memorial: Fondo de Cultura Económica

Azevedo, R.M. de (1994) Las ideas de Ricardo Severo y la relación con el academicismo, in Amaral, A.A. (ed.) Arquitectura neocolonial: América Latina, Caribe, Estados unidos. São Paulo: Memorial: Fondo de Cultura Económica, pp. 249-258.

Campello, $G$. de $O$. (2001) O britho da simplicidade: dois estudos sobre arquitetura refigiosa no Brasil cotonial. Rio de Janeiro: Casa da Palavra: Departamento Nacional do Livro.

Comas, C.E.D. (2010) O passado mora ao lado: Lúcio Costa e o projeto do Grand Hotel de Ouro Preto, 1938/40. Arquitextos, 122(00). Available at: http://www vitruvius com br/revistas/read/arquitextos/11.122/3486.

Costa, L. (2007a) Carta-depoimento, in Sôbre arquitetura. Porto Alegre: Editora UniFitter, pp. 119-128.

Costa, L. (2007b) Consideraçōes sôbre o ensino da arquitetura, in Sôbre arquitetura. Porto Alegre: Editora UniRitter, pp. 111-117.

Costa L (2007c) Documenlacão necessária, in Sobbre arquitetura. Porto Alegre: Editora Unifilter, pp. 86-94

Eliade, M. (1966) Aspects du mythe. Paris: Gallimard.

Fonseca, M.C.L. (2005) O património em processo: trajetória da politica federal de preservaçäo no Brasit 2nded. Rio de Janeiro: Editora UFRJ: MinC-IPHAN.

Gonzaga Duque Estrada, L. (1929) Contemporaneos: pintores e esculptores. Benedicto de Souza.

Gonzaga Duque Estrada, L. (1995) A arte brasiteira, T. Chiarelli (ed.). Campinas Mercado de Letras.
Kessel, C. (2008) Arqutetura neocolonial no Brasit: entre o pastiche e a modemidade. Rio de Janeiro: Universidade Estácio de Sá, Curso de Arquitetura e Urbanismo Jauá Editora.

Lemos, C.A. (1987) Ecletismo em Sáo Paulo, in Fabris, A. (ed.) Ecletismo na arquitetura brasileira. Sāo Paulo: Nobel/Edusp, pp, 69-103

Marianno Filho, J. (1943) À margem do problema arqúftetônico nacional. Rio de vaneiro Mendes Junio

Mayumi, L. (2008) Taipa, canela-preta e concreto: estudo sobre o restauro de casas bandeiristas. São Paulo: Romano Guerra.

Mello, J. (2007) Ricardo Severo: da arqueologia portuguesa à arquitetura brasiteira, São Paulo: Annablume.

Monteiro Lobato, J.B. (1919) Cidades mortas.' contos e impressões. Săo Paulo: Revista do Brasil.

Monteiro Lobato, J.B.M. (1944) Urupês, 2nd ed. São Paulo: Martins.

Morales de los Rios Filho, A. (1941) Grandjean de Montigny e a evoluçấo da arte brasiteira. Rio de Janeiro: A Noite.

Pereira, M. da S. (ed.) (2011) 1908 um Brasif em exposiçăo. Rio de Janeiro: Casa 12.

Pinheiro, M.L.B. (2012) Neocoloniat, modernismo e preservaçāo do patrimonto no debate cutural dos anos 1920 no Brasit. São Paulo: EdUSP

Puppi, M. (1998) Por uma historia näo modema da arquitetura brasiteira; questóes de historiografia. Campinas: Pontes: Unicamp.

Rodrigues, J.W. (1975) Documentário arquitetônico: relativo à antiga construção civit no Brasit. São Paulo: Livraria Martins Editore.

Severo, R. (1917) A arte tradicional no Brasil. Revista do Brasif, 2(4), pp. 394-424.

Sitva, L.M. da (2012) Cidades Mortas: o declínio da 'civilização caleeira' no vale do Paraíba segundo a elite agrária decadente. lóéias, 1(4). Available at: http://Mrww. ifch.unicamp.br/ojs/index.php/ideias/article/view/867.

Silva, M.V. da (2013) A modernidade em Monteiro Lobato: Cidades Mortas e o retrato de um Brasil decadente no início do século XX. Revista Virtual de Letras, $\mathbf{5}(1)$, pp. 293-308. Available at: http://Www revletcom br/artigos/18g pdf 